\title{
PENERAPAN MODEL PBL UNTUK MENINGKATKAN KEMAMPUAN PEMECAHAN MASALAH MATEMATIKA PESERTA DIDIK KELAS XII MIPA2 SMAN 12 PEKANBARU
}

\author{
Jhoni Putra ${ }^{1)}$, Yulita ${ }^{2)}$ \\ ${ }^{1)}$ Pendidikan Matematika, Universitas Riau \\ ${ }^{2)}$ SMA Negeri 12 Pekanbaru \\ Email : jhoniputra513@gmail.com
}

\begin{abstract}
Abstrak. Kurang baiknya kemampuan pemecahan masalah matematika (KPMM) merupakan hal yang sangat penting untuk diperhatikan. Karena kemampuan ini memegang peranan yang sangat menentukan dalam perkembangan ilmu pengetahuan dan teknologi. Tujuan dari penelitian ini adalah untuk meningkatkan kemampuan pemecahan matematika peserta didik melalui penerapan model problem based learning bagi peserta didik kelas XII MIPA 2 SMAN 12 Pekanbaru. Penelitian ini merupakan penelitian tindakan kelas (PTK) yang dilakukan dalam dua siklus. Hasil penelitian menunjukkan terjadi perbaikan proses pembelajaran dan peningkatan kemampuan pemecahan masalah peserta didik. Hal ini terlihat dari peningkatan jumlah peserta didik pada kualifikasi sangat baik, yaitu sejumlah 27 orang dan pada kualifikasi baik sejumlah 9 orang, serta kualifikasi cukup sebanyak 3 orang dan tidak ada satu pun peserta didik pada kualifikasi kurang serta sangat kurang.
\end{abstract}

Kata Kunci: Problem Based Learning, Kemampuan pemecahan masalah, Penelitian tindakan kelas

\section{PENDAHULUAN}

Matematika merupakan suatu disiplin ilmu yang memegang peranan penting dalam perkembangan ilmu pengetahuan dan teknologi. Oleh karena itu, untuk menguasai dan menciptakan teknologi di masa depan diperlukan penguasaan matematika yang kuat sejak dini. Sebagaimana amanat Kemendikbud dalam Permendikbud nomor 103 tahun 2014, pembelajaran ialah proses interaksi antara peserta didik dengan pendidik dan dengan sumber belajar pada suatu lingkungan belajar. Pembelajaran dilaksanakan berbasis aktivitas dengan karakteristik: (1) interaktif dan inspiratif; (2) menyenangkan, menantang, dan memotivasi peserta didik untuk berpartisipasi aktif; (3) kontekstual dan kolaboratif; (4) memberikan ruang yang cukup bagi prakarsa, kreativitas, dan kemandirian peserta didik; dan (5) sesuai dengan bakat, minat, kemampuan, dan perkembangan fisik serta psikologis peserta didik.

Sebagai suatu disiplin ilmu, matematika memiliki tujuan pembelajaran, seperti tertuang dalam Permendikbud nomor 58 tahun 2014, diantaranya: (1) memahami keterkaitan antar konsep dalam pemecahan masalah; (2) menggunakan pola sebagai dugaan dalam penyelesaian masalah dan membuat generalisasi berdasarkan fenomena atau data yang ada; (3) menggunakan penalaran pada sifat, melakukan manipulasi matematika baik dalam penyederhanaan, maupun menganalisa komponen yang ada dalam pemecahan masalah, dalam konteks matematika maupun di luar matematika; (4) mengomunikasikan gagasan, penalaran serta mampu manyusun bukti matematika dengan menggunakan kalimat lengkap, simbol, tabel, diagram, atau media lain untuk memperjelas keadaan atau masalah; (5) memiliki sikap menghargai kegunaan matematika dalam kehidupan, yaitu memiliki rasa ingin tahu, perhatian, dan minat dalam mempelajari matematika, serta sikap ulet dan percaya diri dalam pemecahan masalah; (6) memiliki sikap dan perilaku yang sesuai dengan nilai-nilai dalam matematika dan pembelajarannya; (7) melakukan kegiatankegiatan motorik yang menggunakan pengetahuan matematika; (8) menggunakan alat peraga sederhana maupun hasil teknologi untuk melakukan kegiatan-kegiatan matematik.

Tujuan pembelajaran di atas, khususnya poin pertama dan kelima adalah salah satu tujuan penting dalam pembelajaran matematika. Pemecahan masalah mencakup proses berpikir tingkat tinggi, seperti proses visualisasi, asosiasi, abstraksi, manipulasi, penalaran, analisis, sintesis, dan generalisasi yang masingmasing perlu dikelola secara terkoordinasi (Suryadi dan Herman, 2008). 
Hasil wawancara peneliti dengan guru matematika mengenai proses pembelajaran di kelas XII MIPA 2 SMAN 12 Pekanbaru, diperoleh informasi bahwa ketika proses pembelajaran berlangsung, peserta didik hanya menerima apa yang disampaikan oleh guru dan tidak berusaha secara mandiri untuk mencari materi penunjang mengenai materi yang dipelajari. Selain itu, peserta didik kurang terbiasa mengerjakan soal pemecahan masalah.

Menurut penuturan guru, usaha yang telah dilakukan guru untuk meningkatkan kemampuan pemecahan masalah matematika (KPMM) peserta didik adalah dengan menerapkan diskusi kelompok di dalam pembelajaran untuk memperbaiki keaktifan peserta didik serta memberikan soal terkait pemecahan masalah, tetapi hanya peserta didik yang memiliki kemampuan kognitif tinggi yang cenderung aktif dalam proses pembelajaran dan mampu menyelesaikan soal pemecahan masalah.

Hasil pengamatan yang dilakukan peneliti ketika proses pembelajaran, pada kegiatan pendahuluan, guru mengawali pembelajaran dengan menginstruksikan peserta didik untuk berdoa, lalu mengumpulkan pekerjaan rumah. Setelah itu, guru menjelaskan materi pembelajaran dilanjutkan dengan pemberian soal, sementara peserta didik menyimak dan menerima apa yang dijelaskan oleh guru. Selanjutnya, peserta didik diberikan kesempatan oleh guru untuk mencatat penjelasan guru dan diberi kesempatan untuk bertanya. Hanya dua orang peserta didik yang mengajukan pertanyaan mengenai materi yang belum dipahami. Pada saat peserta didik diberikan soal berbentuk pemecahan masalah, guru sudah mengarahkan peserta didik pada solusi permasalahan, namun peserta didik masih tidak memahami langkah-langkah penyelesaian soal pemecahan masalah tersebut. Selanjutnya, komunikasi antara guru dan peserta didik terlihat berjalan satu arah, dimana guru menjadi pusat kegiatan pembelajaran.

Berdasarkan pengamatan tersebut, peneliti melakukan tes awal kemampuan pemecahan masalah tentang materi yang telah dipelajari peserta didik pada kelas VII SMP, yaitu pada Kompetensi Dasar 3.12 Menganalisis hubungan antara data dengan cara penyajiannya (tabel, diagram garis, diagram batang, dan diagram lingkaran). Soal tes awal yang diberikan kepada peserta didik merujuk pada tahap-tahap dalam proses pemecahan masalah. Rata-rata skor awal tes KPMM peserta didik untuk setiap aspek dapat dilihat dari Tabel 1 berikut.

Tabel 1. Persentase KPMM Peserta Didik Kelas XII MIPA 2 SMAN 12 Pekanbaru

\begin{tabular}{lcccc}
\hline & \multicolumn{2}{c}{ Soal 1 } & \multicolumn{2}{c}{ Soal 2 } \\
\cline { 2 - 5 } $\begin{array}{l}\text { Aspek yang } \\
\text { diukur }\end{array}$ & $\begin{array}{c}\text { Jumla } \\
\text { h } \\
\text { peserta } \\
\text { didik }\end{array}$ & $\begin{array}{c}\text { Jumla } \\
\text { h } \\
\text { peserta } \\
\text { didik }\end{array}$ & $\%$ \\
\hline $\begin{array}{l}\text { Memahami } \\
\text { masalah }\end{array}$ & 13 & 33, & 11 & 28, \\
$\begin{array}{l}\text { Merencanaka } \\
\text { n pemecahan }\end{array}$ & 11 & 28, & 6 & 15, \\
$\begin{array}{l}\text { masalah } \\
\text { Melaksanaka }\end{array}$ & 8 & 20, & 3 & 7,6 \\
$\begin{array}{l}\text { n rencana } \\
\text { pemecahan }\end{array}$ & & 5 & & \\
$\begin{array}{l}\text { masalah } \\
\text { Menafsirkan } \\
\text { solusi }\end{array}$ & 0 & 0 & 0 & 0 \\
\hline
\end{tabular}

Berdasarkan Tabel 1 terlihat bahwa KPMM peserta didik belum baik. Dari 39 orang jumlah peserta didik, hanya delapan orang peserta didik yang dapat melaksanakan rencana pemecahan masalah dengan benar pada soal no 1 , namun tidak ada satupun peserta didik yang benar pada aspek menafsirkan solusi. Kenyataan yang mencolok juga terjadi pada aspek memahami masalah yaitu hanya 13 peserta didik dari 39 peserta didik di kelas yang dapat menjawab dengan benar, padahal aspek ini berkaitan dengan menuliskan yang diketahui dan ditanyakan dari soal tersebut.

Hasil wawancara peneliti dengan peserta didik mengenai tes yang telah dilakukan, diperoleh informasi sebagai berikut: (1) soal yang diberikan sulit sehingga peserta didik tidak dapat menyelesaikannya; (2) peserta didik bingung menentukan cara pengerjaan soal, sehingga peserta didik hanya menyelesaikan soal tersebut menurut cara mereka sendiri.

Berdasarkan uraian di atas, terdapat masalah yang terjadi di kelas XII MIPA 2 SMAN 12 Pekanbaru. Permasalahan tersebut di antaranya peserta didik kurang aktif dalam proses pembelajaran, serta yang paling utama adalah peserta didik tidak mampu menyelesaikan soal pemecahan masalah 
sehingga menyebabkan kemampuan pemecahan masalah matematika peserta didik rendah.

Berdasarkan permasalahan yang telah dipaparkan di atas, perlu suatu model pembelajaran yang dapat meningkatkan keaktifan peserta didik dalam belajar, merangsang peserta didik berpikir kritis, dapat mengaplikasikan konsep dalam kehidupan nyata, bekerja aktif dalam tim untuk memecahkan masalah yang ada dengan suasana menyenangkan sehingga pembelajaran berpusat pada peserta didik, serta dapat meningkatkan kemampuan pemecahan masalah matematika peserta didik.

Permendikbud Nomor 104 Tahun 2014 memandang peserta didik sebagai subjek yang memiliki kemampuan untuk secara aktif mencari, mengolah, mengonstruksi, dan menggunakan pengetahuan. Maka pembelajaran harus berkenaan dengan kesempatan yang diberikan kepada peserta didik untuk mengonstruksi pengetahuan dalam proses kognitifnya. Peserta didik perlu didorong untuk bekerja memecahkan masalah, menemukan segala sesuatu untuk dirinya, dan berupaya keras mewujudkan ide-idenya agar benar-benar memahami dan dapat menerapkan pengetahuan. Salah satu model pembelajaran yang dapat melatih kemampuan pemecahan masalah matematika peserta didik yaitu model pembelajaran Problem Based Learning (PBL).

Menurut Arends (2013), PBL adalah model pembelajaran dengan pendekatan pembelajaran peserta didik pada masalah autentik, sehingga peserta didik dapat menyusun pengetahuannya sendiri, mengembangkan keterampilan yang lebih tinggi dan inkuiri, memandirikan peserta didik, dan meningkatkan kepercayaan diri sendiri. Oleh karena itu, PBL menuntut peserta didik untuk lebih aktif dan mandiri dalam mencari informasi tentang materi yang diajarkan.

Permendikbud Nomor 58 Tahun 2014 menyatakan bahwa PBL adalah proses pembelajaran yang titik awal pembelajaran dimulai berdasarkan masalah dalam kehidupan nyata. Peserta didik dirangsang untuk mempelajari masalah berdasarkan pengetahuan dan pengalaman yang mereka miliki sebelumnya (prior knowledge), untuk membentuk pengetahuan dan pengalaman baru.

Pelaksanaan PBL menggunakan pendekatan pembelajaran saintifik/pendekatan berbasis proses keilmuan. Pendekatan saintifik/pendekatan berbasis proses keilmuan merupakan pengorganisasian pengalaman belajar dengan urutan logis meliputi proses pembelajaran: (1) mengamati; (2) menanya; (3) mengumpulkan informasi atau mencoba; (4) menalar atau mengasosiasi; dan (5) mengomunikasikan. Model pembelajaran yang sesuai dengan kerangka konseptual dan operasional pembelajaran, yang memiliki nama, ciri, urutan logis, pengaturan, dan budaya. Metode pembelajaran yang digunakan oleh untuk menangani suatu kegiatan pembelajaran antara lain ceramah, tanya jawab, dan diskusi (Kemendikbud, 2014).

Berdasarkan uraian tersebut, terlihat bahwa PBL merupakan model pembelajaran yang dapat memberikan kondisi belajar yang aktif kepada peserta didik karena melibatkan peserta didik dalam memecahkan masalah melalui kegiatan ilmiah. Oleh karena itu, perlu adanya penelitian mengenai penerapan model Problem Based Learning (PBL) untuk meningkatkan kemampuan pemecahan masalah matematika peserta didik kelas XII MIPA 2 SMAN 12 Pekanbaru, semester ganjil 2018/2019 pada materi Statistika. Peneliti memilih materi ini karena materi pembelajaran tersebut banyak diterapkan pada kehidupan sehari-hari. Selain itu, tujuan pemilihan materi ini agar model pembelajaran PBL dapat meningkatkan kemampuan peserta didik dalam berpikir logis dan sistematis dalam kehidupan nyata.

\section{METODE}

Penelitian ini dilaksanakan di kelas XII MIPA 2 SMAN 12 Pekanbaru, pada semester ganjil tahun pelajaran 2018/2019. Pelaksanaan tindakan berupa penerapan PBL dimulai dari bulan September 2018 sampai dengan bulan Oktober 2018.

Bentuk penelitian ini adalah Penelitian Tindakan Kelas (PTK) pola kolaboratif. PTK pola kolaboratif ini dilaksanakan oleh pihak luar, dimana guru hanya berperan sebagai anggota tim peneliti, yang berfungsi melaksanakan tindakan seperti yang dirancang oleh peneliti (Sanjaya, 2013).

Penelitian ini terdiri dari dua siklus, yaitu dengan melakukan tindakan yang mengacu pada penerapan PBL. Terdapat empat tahap dalam pelaksanaan penelitian tindakan kelas ini 
menurut Arikunto, Suhardjono, dan Supardi (2012) yaitu perencanaan, pelaksanaan, pengamatan, dan refleksi. Model siklus penelitian tindakan kelas digambarkan sepertii pada Gambar 1 berikut.

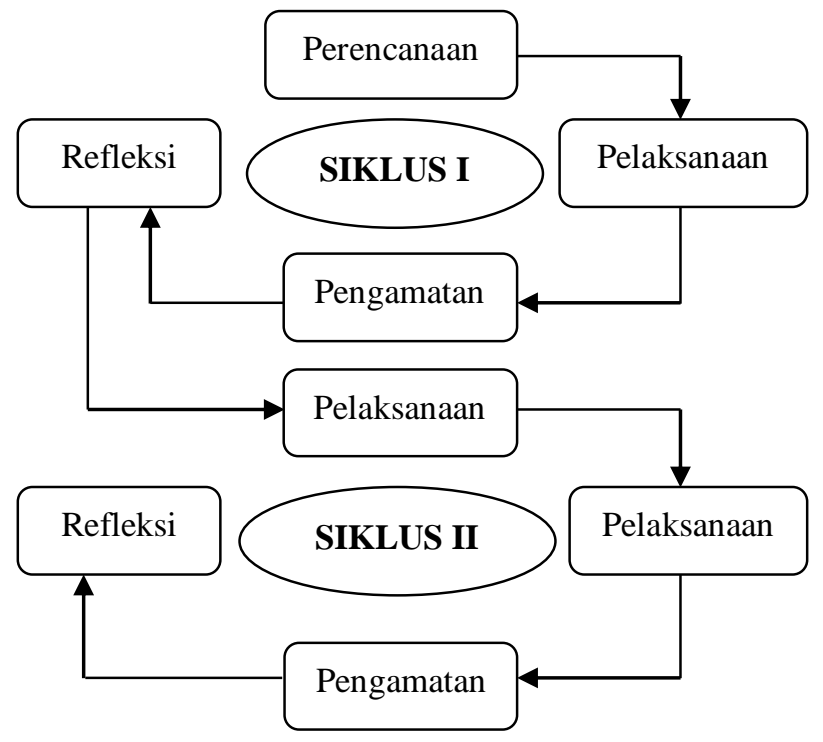

Gambar 1. Siklus Penelitian Tindakan Kelas

Kegiatan yang dilakukan pada setiap tahap adalah sebagai berikut.

1. Perencanaan (planning)

Pada tahap perencanaan ini peneliti menyusun Rencana Pelaksanaan Pembelajaran (RPP), Lembar Kegiatan Peserta Didik (LKPD), lembar pengamatan, menentukan skor awal KPMM peserta didik yang diperoleh dari hasil tes pada materi yang sudah mereka pahami sebelumnya dan mengelompokkan peserta didik. Kemudian peneliti berdiskusi dengan guru matematika.

2. Pelaksanaan tindakan (action).

Pada tahap ini, peneliti bertindak sebagai guru dan guru sebagai pengamat dalam melaksanakan proses pembelajaran yang berpedoman pada rencana pelaksanaan pembelajaran yang telah disusun. Peneliti melakukan kegiatan pembelajaran sesuai dengan RPP-1 sampai RPP-4 yang dilaksanakan pada siklus I, sedangkan RPP-5 sampai RPP-7 dilaksanakan pada siklus II.

3. Pengamatan (Observing).

Kegiatan ini dilakukan untuk menelaah kondisi objektif pada saat tindakan dilakukan. Guru sebagai pengamat mengamati peneliti dengan menggunakan lembar pengamatan aktivitas guru dan peserta didik tentang bagaimana proses belajar mengajar berlangsung yang akan ditinjau dari aspek peserta didik, peneliti, materi, media pembelajaran, dan model pembelajaran yang akan digunakan, serta bagaimana hasil belajar yang dicapai oleh peserta didik.

4. Refleksi (Reflecting)

Pada tahap ini, peneliti dan guru membahas hasil pengamatan pelaksanaan pembelajaran setiap pertemuan. Hal ini bertujuan untuk menghasilkan rekonstruksi terhadap proses pembelajaran yang telah peneliti lakukan sehingga memberikan dasar perbaikan pada perencanaan tindakan berikutnya.

Data KPMM peserta didik diperoleh berdasarkan nilai tes evaluasi akhir. Penilaian tes evaluasi akhir mengacu kepada pedoman penskoran yang diadaptasi dari Hamzah (2014). Kriteria pemberian skor untuk setiap indikator KPMM peserta didik seperti pada Tabel 2 berikut.

Tabel 2. Pedoman Penskoran KPMM Peserta Didik

\begin{tabular}{|c|c|c|}
\hline $\begin{array}{c}\text { Aspek yang } \\
\text { Dinilai }\end{array}$ & $\begin{array}{c}\text { Sko } \\
\mathbf{r}\end{array}$ & Keterangan \\
\hline \multirow[t]{4}{*}{$\begin{array}{l}\text { Memahami } \\
\text { masalah }\end{array}$} & 0 & $\begin{array}{l}\text { Tidak menyebutkan apa } \\
\text { yang diketahui dan apa yang } \\
\text { ditanyakan. }\end{array}$ \\
\hline & 1 & $\begin{array}{l}\text { Menyebutkan apa yang } \\
\text { diketahui tanpa } \\
\text { menyebutkan apa yang } \\
\text { ditanyakan atau sebaliknya. }\end{array}$ \\
\hline & 2 & $\begin{array}{l}\text { Menyebutkan apa yang } \\
\text { diketahui dan apa yang } \\
\text { ditanyakan tetapi kurang } \\
\text { tepat. }\end{array}$ \\
\hline & 3 & $\begin{array}{l}\text { Menyebutkan apa yang } \\
\text { diketahui dan apa yang } \\
\text { ditanyakan secara tepat. }\end{array}$ \\
\hline \multirow[t]{3}{*}{$\begin{array}{l}\text { Merencanakan } \\
\text { penyelesaian }\end{array}$} & 0 & $\begin{array}{l}\text { Tidak merencanakan } \\
\text { penyelesaian masalah sama } \\
\text { sekali. }\end{array}$ \\
\hline & 1 & $\begin{array}{l}\text { Merencanakan penyelesaian } \\
\text { dengan membuat model } \\
\text { matematika berdasarkan } \\
\text { masalah tetapi model } \\
\text { matematika kurang tepat. }\end{array}$ \\
\hline & 2 & $\begin{array}{l}\text { Merencanakan penyelesaian } \\
\text { dengan membuat model } \\
\text { matematika berdasarkan } \\
\text { masalah secara tepat. }\end{array}$ \\
\hline \multirow[t]{2}{*}{$\begin{array}{l}\text { Melaksanakan } \\
\text { rencana }\end{array}$} & 0 & $\begin{array}{l}\text { Tidak ada jawaban sama } \\
\text { sekali. }\end{array}$ \\
\hline & 1 & Melaksanakan rencana \\
\hline
\end{tabular}




\begin{tabular}{lll}
\hline \hline & & $\begin{array}{l}\text { dengan menuliskan jawaban } \\
\text { tetapi jawaban salah satu } \\
\text { atau hanya sebagian kecil } \\
\text { jawaban benar. } \\
\text { Melaksanakan rencana } \\
\text { dengan menuliskan jawaban } \\
\text { setengah atau sebagian besar } \\
\text { jawaban benar. } \\
\text { Melaksanakan rencana } \\
\text { dengan menuliskan jawaban } \\
\text { dengan lengkap dan benar. } \\
\text { Tidak ada menuliskan } \\
\text { Menafsirkan } \\
\text { hasil yang }\end{array}$ \\
diperoleh & 1 & $\begin{array}{l}\text { kesimpulan. } \\
\text { Menafsirkan hasil yang } \\
\text { diperoleh dengan membuat } \\
\text { kesimpulan tetapi kurang } \\
\text { tepat. } \\
\text { Menafsirkan hasil yang } \\
\text { diperoleh dengan membuat } \\
\text { kesimpulan dengan tepat. }\end{array}$ \\
\hline
\end{tabular}

Sumber: Hamzah, 2014

Data yang diperoleh dari tes KPMMpeserta didik dianalisis dengan teknik analisis statistik deskriptif. Menurut Sugiyono (2012), statistik deskriptif adalah statistik yang digunakan untuk menganalisis data dengan cara mendeskripsikan atau menggambarkan data yang telah terkumpul sebagaimana adanya tanpa bermaksud membuat kesimpulan yang berlaku umum atau generalisasi.

Data hasil pengamatan kegiatan guru dan kegiatan peserta didik dianalisis secara kualitatif (Arikunto, 2012). Miles dan Huberman (Muslich, 2010) mengemukakan bahwa analisis data kualitatif melalui tiga tahapan, yaitu:

1. Reduksi data, merupakan proses menyeleksi, menentukan fokus, menyederhanakan, meringkas, dan mengubah bentuk data 'mentah' yang ada dalam catatan hasil pengamatan kegiatan guru dan kegiatan peserta didik. Dalam proses ini dilakukan penajaman, pemilahan, pemfokusan, penyisihan data yang kurang bermakna, dan menatanya sedemikian rupa sehingga dari proses pembelajaran dengan model PBL dapat ditarik kesimpulan akhir dan diverifikasi.

2. Paparan data, merupakan penjabaran data hasil pengamatan kegiatan guru dan kegiatan peserta didik setelah melalui proses pembelajaran dengan model PBL dalam bentuk narasi sedemikian rupa sehingga dapat dipahami secara jelas.
3. Penyimpulan, merupakan upaya memberikan penilaian atau interpretasi berdasarkan paparan data yang telah dilakukan. Penarikan kesimpulan tentang kegiatan guru dan kegiatan peserta didik dilakukan secara bertahap mulai dari kesimpulan sementara yang ditarik pada akhir siklus I, sampai pada kesimpulan akhir siklus II.

Analisis data yang dilakukan pada penelitian ini yaitu sebagai berikut.

1. Analisis Data Pencapaian Kemampuan Pemecahan Masalah Matematika Peserta Didik

Analisis data hasil tes kemampuan pemecahan masalah matematika peserta didik siklus I dan siklus II dianalisis secara kuantitatif untuk mengetahui tingkat kemampuan pemecahan masalah awal peserta didik, kemampuan pemecahan masalah peserta didik pada siklus I, dan pada siklus II. Langkahlangkah yang dilakukan dalam pengolahan data tes kemampuan pemecahan masalah peserta didik yaitu (1) memberikan skor jawaban peserta didik sesuai dengan pedoman penskoran yang digunakan lalu dikonversi menjadi skor kemampuan pemecahan masalah peserta didik dengan rentang 0-100; (2) membuat tabel rerata skor kemampuan pemecahan masalah awal peserta didik, skor KPMM peserta didik pada siklus I dan siklus II.

Konversi skor KPMM peserta didik menggunakan rumus:

Skor siswa $=\frac{\text { Skor Perolehan }}{\text { Skor Maksimal }} \times 100$

Nilai KPMM yang diperoleh dari perhitungan kemudian dikualifikasikan sesuai dengan tabel 3 berikut ini.

Tabel 3. Kualifikasi KPMM Peserta Didik

\begin{tabular}{cc}
\hline Nilai & Kualifikasi \\
\hline $85,00-100$ & Sangat baik \\
$70,00-84,99$ & Baik \\
$55,00-69,99$ & Cukup \\
$40,00-54,99$ & Kurang \\
$0-39,99$ & Sangat kurang \\
\hline
\end{tabular}

Sumber: Japa dalam Mawaddah dan Anisah, 2015

Salah satu cara yang dapat digunakan untuk melihat peningkatan KPMM didik adalah dengan melihat peningkatan rata-rata dan persentase keberhasilan belajar peserta didik (Arikunto, 2014). Pada penelitian ini, KPMM 
peserta didik dikatakan mengalami peningkatan apabila terjadi peningkatan rata-rata skor KPMM peserta didik dari skor dasar ke skor tes KPMM siklus I dan siklus II.

2. Analisis Keberhasilan Tindakan

Menurut Sanjaya (2013), PTK dikatakan berhasil jika masalah yang dikaji semakin mengerucut atau melalui tindakan setiap siklus masalah semakin terpecahkan; sedangkan dilihat dari aspek hasil belajar, pencapaian peserta didik semakin besar, artinya hasil belajar dari siklus ke siklus semakin meningkat. Semakin kecilnya masalah dan semakin besarnya hasil belajar peserta didik disebabkan oleh tindakan yang dilakukan guru pada setiap siklus yang didasarkan pada hasil refleksi. Kriteria keberhasilan tindakan pada penelitian ini adalah sebagai berikut.

a. Terjadinya Perbaikan Proses Pembelajaran Terjadinya perbaikan proses pembelajaran jika kegiatan guru dan kegiatan peserta didik mengalami peningkatan. Kesesuaian antara langkah-langkah penerapan model pembelajaran PBL yang direncanakan dengan pelaksanaan tindakan pada proses pembelajaran, dapat dilihat dari lembar pengamatan setiap pertemuan. Perbaikan proses pembelajaran dilakukan berdasarkan hasil refleksi terhadap proses pembelajaran yang diperoleh melalui lembar pengamatan kegiatan guru dan kegiatan peserta didik.

b. Peningkatan KPMM Peserta Didik

Pada penelitian ini, KPMM peserta didik dikatakan mengalami peningkatan apabila terjadi peningkatan skor KPMM peserta didik dari skor awal ke skor tes siklus I dan skor untuk siklus II.

\section{HASIL DAN PEMBAHASAN}

Hasil penelitian yang dianalisis yaitu aktivitas guru dan aktivitas peserta didik selama proses pembelajaran dan KPMM peserta didik yang diambil dari hasil ulangan harian peserta didik.

\section{Analisis Aktivitas Guru dan Aktivitas Peserta Didik \\ Kesesuaian langkah-langkah penerapan} PBL yang direncanakan dengan pelaksanaan tindakan proses pembelajaran dapat dilihat dari lembar pengamatan pada setiap pertemuan. Kekurangan proses pembelajaran pada siklus II semakin sedikit pada setiap pertemuan. Kekurangan proses pembelajaran pada siklus II mampu diatasi peneliti lebih baik daripada siklus I. Hal ini berarti aktivitas peneliti dan aktivitas peserta didik pada siklus kedua semakin baik. Hal ini dapat dilihat pada Tabel 4 berikut.

Tabel 4. Analisis Aktivitas Guru dan Aktivitas Peserta Didik

\begin{tabular}{|c|c|c|}
\hline No & $\begin{array}{c}\text { Kegiatan } \\
\text { Pembelajaran } \\
\end{array}$ & Hasil Analisis \\
\hline 1 & $\begin{array}{l}\text { Peserta didik } \\
\text { berdoa } \\
\text { dipimpin oleh } \\
\text { ketua kelas }\end{array}$ & $\begin{array}{l}\text { Pada setiap pertemuan, } \\
\text { peserta didik memulai } \\
\text { pembelajaran dengan } \\
\text { berdoa bersama yang } \\
\text { dipimpin oleh ketua kelas. } \\
\text { Pada pertemuan pertama, } \\
\text { terdapat tiga orang peserta } \\
\text { didik yang tidak serius } \\
\text { dalam berdoa. Pada } \\
\text { pertemuan kedua, tiga } \\
\text { orang peserta didik yang } \\
\text { bermain-main dalam } \\
\text { berdoa diberi nasehat oleh } \\
\text { peneliti. Pada pertemuan } \\
\text { ketiga, peserta didik sudah } \\
\text { tampak baik dalam } \\
\text { berdoa. Pada pertemuan } \\
\text { keempat sampai } \\
\text { seterusnya, seluruh peserta } \\
\text { didik berdoa dengan } \\
\text { serius. }\end{array}$ \\
\hline 2 & $\begin{array}{l}\text { Guru mengecek } \\
\text { kehadiran } \\
\text { peserta didik }\end{array}$ & $\begin{array}{l}\text { Pada pertemuan pertama } \\
\text { sampai kelima terdapat } \\
\text { satu orang yang sering } \\
\text { absen tanpa keterangan. } \\
\text { Namun pada pertemuan } \\
\text { keenam dan seterusnya } \\
\text { peserta didik tersebut } \\
\text { hadir. }\end{array}$ \\
\hline 3 & $\begin{array}{l}\text { Guru } \\
\text { menyampaikan } \\
\text { tujuan } \\
\text { pembelajaran }\end{array}$ & $\begin{array}{l}\text { Pada pertemuan pertama } \\
\text { hingga pertemuan } \\
\text { ketujuh, guru selalu } \\
\text { menyampaikan tujuan } \\
\text { pembelajaran, baik } \\
\text { secara lisan maupun } \\
\text { tulisan. }\end{array}$ \\
\hline 4 & $\begin{array}{l}\text { Guru memberi } \\
\text { motivasi } \\
\text { kepada peserta } \\
\text { didik mengenai } \\
\text { pembelajaran } \\
\text { yang akan } \\
\text { dilakukan } \\
\text { dengan } \\
\text { permasalahan } \\
\text { pada kehidupan } \\
\text { sehari-hari. }\end{array}$ & $\begin{array}{l}\text { Pada pertemuan pertama } \\
\text { guru menyampaikan } \\
\text { motivasi, peserta didik } \\
\text { cenderung pasif dalam } \\
\text { menanggapi } \\
\text { penyampaian guru. Hal } \\
\text { ini juga terjadi pada } \\
\text { pertemuan kedua. Pada } \\
\text { pertemuan ketiga dan } \\
\text { seterusnya, peserta didik } \\
\text { mulai aktif dalam } \\
\text { memberi respon terhadap }\end{array}$ \\
\hline
\end{tabular}


5 Guru melakukan apersepsi.

6 Guru menyampaikan langkahlangkah pembelajaran dilakukan yang akan

penyampaian guru. Guru

juga berusaha agar peserta didik memberi respon terhadap penyampaiannya.

Pada pertemuan pertama guru melakukan apersepsi, hanya tujuh orang peserta didik yang mau mengangkat tangan untuk menjawab soal. Pada pertemuan kedua, beberapa peserta didik sudah mulai mengangkat tangan untuk menjawab soal. Pada pertemuan selanjutnya, peserta didik sudah aktif dalam menjawab apersepsi yang diberikan guru. Guru berusaha menyuruh peserta didik yang berbeda untuk menjawab apersepsi pada setiap pertemuan.

Pada pertemuan pertama guru menjelaskan kepada peserta didik bahwa pembelajaran akan dilakukan secara berkelompok dengan menggunakan LKPD. Peserta didik memperhatikan penjelasan guru meskipun peserta didik masih belum memahami dengan jelas bagaimana proses pembelajaran yang akan dilakukan. Hal ini terjadi hingga pada pertemuan ketiga. Pada pertemuan selanjutnya, peserta didik sudah dapat memahami langkahlangkah pembelajaran yang dilakukan.

7 Guru membagi peserta didik secara berkelompok
Pada pertemuan pertama, pembentukan kelompok tidak tertib. Pada pertemuan kedua, pembentukan kelompok belajar masih tidak tertib dan tidak tenang. Pada pertemuan ketiga dan seterusnya, peserta didik sudah mulai tenang dan tertib dalam

pembentukan kelompok. Walaupun di pertemuan kelima terjadi pertukaran kelompok yang membuat peserta didik sedikit kecewa, namun itu semua bisa diatasi oleh peneliti.

8 Peserta didik Pada pertemuan pertama, mempelajari peserta didik bingung permasalahan dalam menjawab pada LKPD dan melakukan penyelidikan.

permasalahan sesuai pada kolomnya. Pada pertemuan kedua, masih ada beberapa kelompok yang belum paham dalam menuliskan jawaban permasalahan sesuai kolomnya. Pada pertemuan ketiga, hanya dua kelompok yang masih bingung dalam menuliskan jawaban permasalahan sesuai kolomnya. Pada pertemuan seterusnya, peserta didik sudah dapat menuliskan jawaban sesuai dengan kolomnya.

9 Peserta didik menyajikan pembahasan permasalahan LKPD di depan kelas.

10 Peserta didik menuliskan kesimpulan
Pada pertemuan pertama, tidak satupun dari kelompok yang dapat menjelaskan hasil pekerjaannya di depan kelas. Peserta didik hanya menuliskan solusi dari permasalahan di papan tulis. Pada pertemuan kedua, peserta didik mulai belajar menjelaskan solusi permasalahan di depan kelas walaupun masih sedikit terbata-bata. Pada pertemuan ketiga, peserta didik mulai terbiasa menjelaskan solusi dari permasalahan. Pada pertemuan selanjutnya, peserta didik dapat menjelaskan solusi dengan baik, terlihat dari suara peserta didik yang terdengar lantang dan sudah tidak terbata-bata. Pada pertemuan pertama dan kedua, peserta didik tidak memahami cara 
LKPD

11 Peserta didik menganalisa dan mengevaluasi proses pemecahan masalah
12 Peserta didik menyimpulkan materi pembelajaran.

13 Guru memberi tes tertulis. menuliskan kesimpulan materi. Pada pertemuan ketiga, beberapa peserta didik mulai paham dan dapat menuliskan kesimpulan pembelajaran. Pada pertemuan selanjutnya, peserta didik dapat menuliskan kesimpulan materi pembelajaran.

Pada pertemuan pertama, peserta didik ragu dalam mengoreksi jawab peserta didik lain di depan kelas. Guru berusaha memancing respon peserta didik untuk membenarkan jawaban peserta didik atau sebaliknya. Pada pertemuan kedua, beberapa peserta didik mulai memberi komentar atas jawaban peserta lain. Pada pertemuan selanjutnya, semakin banyak peserta didik yang memberi komentar. Pada pertemuan pertama, peserta didik ragu dalam menyimpulkan materi pembelajaran. Guru berusaha memancing peserta didik untuk menyampaikan pengetahuannya. Pada pertemuan kedua, beberapa peserta didik mengacungkan tangan untuk menyimpulkan materi pembelajaran. Pada pertemuan selanjutnya, semakin banyak peserta didik yang mengacungkan tangan untuk menyimpulkan materi pembelajaran.

Pada pertemuan pertama, guru tidak memberi tes formatif. Pada pertemuan selanjutnya, peserta didik selalu diberikan tes formatif

\section{Analisis KPMM Peserta Didik}

Berikut ini analisis KPMM peserta didik kelas XII MIPA 2 SMAN 12 Pekanbaru setelah dilakukan penerapan model PBL pada materi Statistika.

a. Ketercapaian Aspek KPMM Setelah Tindakan pada Siklus I

Berdasarkan analisis hasil tes KPMM 1 (Ulangan Harian I) diperoleh persentase peserta didik yang mencapai skor maksimum untuk setiap aspek KPMM dapat dilihat pada Tabel 5 berikut.

Tabel 5. Persentase KPMM Peserta Didik Kelas XII MIPA 2 SMAN 12 pada Siklus I

\begin{tabular}{lccc}
\hline \multirow{2}{*}{\multicolumn{1}{c}{ Aspek }} & \multicolumn{3}{c}{ Nomor Soal } \\
\cline { 2 - 4 } & $\mathbf{1}$ & $\mathbf{2}$ & $\mathbf{3}$ \\
\hline Memahami masalah & $61,5 \%$ & $56,4 \%$ & $53,8 \%$ \\
Merencanakan & $51,2 \%$ & $51,2 \%$ & $46,1 \%$ \\
pemecahan masalah & & & \\
Melaksanakan & $43,5 \%$ & $38,4 \%$ & $33,3 \%$ \\
rencana & & & \\
penyelesaian & & & \\
Menafsirkan solusi & $35,8 \%$ & $30,7 \%$ & $28,2 \%$ \\
\hline
\end{tabular}

Berdasarkan data pada Tabel 5, diperoleh informasi bahwa skor pada setiap aspek siklus I meningkat dari skor pada tes awal. Pada soal pertama, terdapat $61,5 \%$ yang sudah mencapai aspek memahami masalah. Begitu juga untuk aspek merencanakan penyelesaian masalah, terlihat persentase yang dicapai oleh peserta didik sebanyak 51,2\% untuk soal no 1 dan 2 , tetapi pada aspek melaksanakan rencana penyelesaian masalah, hanya $43,5 \%$ yang bisa mengerjakan. Ini disebabkan hampir seluruh peserta didik kebingungan untuk menyelesaikan jawaban karena waktu yang tidak mencukupi. Ini juga terlihat pada soal no 2 dan no 3 , hanya sebagian peserta didik yang mencapai skor maksimum tiap aspek KPMM. Kesalahan jawaban yang dilakukan oleh peserta didik dalam mengerjakan tes KPMM pada siklus I diuraikan sebagai berikut.

1) Aspek memahami masalah: peserta didik menuliskan informasi yang diketahui dan ditanyakan dari permasalahan. Pada aspek memahami masalah, masih ada beberapa peserta didik yang tidak menuliskan diketahui dan ditanya serta ada juga beberapa peserta didik yang kurang lengkap dalam menuliskan yang diketahui dan ditanyakan dari permasalahan. Hal ini menyebabkan peserta didik tidak memperoleh skor maksimum

2) Aspek merencanakan pemecahan masalah: Sebagian peserta didik sudah mampu 
menyusun model matematika dari permasalahan yang diberikan dan memilih metode pemecahan masalah secara tepat. Namun ada juga peserta didik yang masih kebingungan untuk merencanakan pemecahan masalah, ini terlihat pada saat peserta didik diminta untuk menyajikan data ke dalam bentuk histogram, ada beberapa peserta didik yang langsung menyajikan data tersebut ke dalam bentuk histogram tapi tidak menuliskan tepi bawah dan tepi atas kelasnya pada tabel, sehingga peserta didik tersebut tidak mendapat skor maksimum.

3) Aspek menyelesaikan rencana penyelesaian masalah: peserta didik menerapkan langkah-langkah pemecahan masalah sesuai rencana dan melakukan perhitungan yang sesuai.

Secara umum, peserta didik telah melaksanakan penyelesaian masalah dengan baik. Hanya saja pada aspek merencanakan penyelesaian masalah peserta didik keliru dalam menuliskan rencana penyelesaian. Selain itu, ada beberapa peserta didik yang tidak dapat menyelesaikan permasalahan tersebut, karena masih bingung dalam memilih soal yang harus diselesaikan terlebih dahulu.

4) Aspek menafsirkan solusi: peserta didik menuliskan kesimpulan dari penyelesaian jawaban soal yang diberikan.

Beberapa peserta didik telah menuliskan kesimpulan dari persoalan yang diberikan. Hanya saja penulisan kesimpulan ini memiliki keterkaitan dengan penyelesaian jawaban pada aspek menyelesaikan permasalahan sesuai rencana. Apabila peserta didik keliru dalam menyelesaikan rencana penyelesaian masalah, maka pada menuliskan kesimpulan, peserta didik juga akan mengalami kesalahan.

\section{b. Ketercapaian Aspek KPMM Setelah Tindakan pada Siklus II \\ Berdasarkan analisis hasil tes KPMM} (Ulangan Harian II) diperoleh persentase peserta didik yang mencapai skor maksimum untuk setiap aspek, dapat dilihat pada Tabel 6 berikut.
Tabel 6. Persentase KPMM Peserta Didik kelas XII MIPA 2 SMAN 12 Pekanbaru pada Siklus II

\begin{tabular}{lcc}
\hline \multirow{2}{*}{\multicolumn{1}{c}{ Aspek }} & \multicolumn{2}{c}{ Nomor Soal } \\
\cline { 2 - 3 } & $\mathbf{1}$ & $\mathbf{2}$ \\
\hline Memahami masalah & $74,3 \%$ & $71,7 \%$ \\
$\begin{array}{l}\text { Merencanakan } \\
\text { pemecahan masalah }\end{array}$ & $76,9 \%$ & $69,2 \%$ \\
$\begin{array}{l}\text { Melaksanakan rencana } \\
\text { penyelesaian }\end{array}$ & $64,1 \%$ & $61,5 \%$ \\
Menafsirkan solusi & $58,9 \%$ & $56,4 \%$ \\
\hline
\end{tabular}

Berdasarkan data pada Tabel 6, diperoleh informasi bahwa skor pada setiap aspek semakin meningkat dari siklus I.

c. Analisis KPMM Peserta Didik Sebelum dan Sesudah Tindakan pada Tiap Aspek

Berikut ini analisis peningkatan KPMM peserta didik pada tiap aspek pemecahan masalah sebelum dan sesudah penerapan model pembelajaran PBL pada materi pokok Ukuran Pemusatan Data dan Ukuran Penyebaran Data.

Tabel 7. Rerata Peningkatan Kemampuan Pemecahan Masalah Matematika Peserta Didik Kelas XII MIPA 2 SMAN 12 Pekanbaru pada Tiap Aspek.

\begin{tabular}{lcc}
\hline \multirow{2}{*}{\multicolumn{1}{c}{ Aspek }} & \multicolumn{2}{c}{$\begin{array}{c}\text { Rerata Skor } \\
\text { Peserta didik }\end{array}$} \\
\cline { 2 - 3 } & Siklus & Siklus II \\
\hline I & 2,32 & 2,71 \\
$\begin{array}{l}\text { Memahami masalah } \\
\text { penyelesanakan masalah }\end{array}$ & 1,49 & 1,64 \\
$\begin{array}{l}\text { Menyelesaikan rencana } \\
\text { penyelesaian masalah }\end{array}$ & 2 & 2,53 \\
Menafsirkan solusi & 1,04 & 1,48 \\
\hline
\end{tabular}

Berdasarkan data pada Tabel 7, diperoleh informasi bahwa peserta didik yang belajar dengan PBL mengalami peningkatan di setiap aspek pemecahan masalah. Hal ini dapat dilihat dari rerata skor tiap aspek pada siklus I dan siklus II. Untuk aspek memahami masalah, rerata skor mengalami peningkatan dari siklus I ke siklus II sebesar 0,39. Pada aspek merencanakan penyelesaian masalah, rerata skor mengalami peningkatan sebesar 0,15 . Pada aspek menyelesaikan rencana penyelesaian masalah, rerata skor mengalami peningkatan sebesar 0,53. Pada aspek menafsirkan solusi, rerata skor mengalami peningkatan sebesar 0,44 . 
d. Analisis KPPM Peserta Didik Sebelum dan Sesudah Tindakan

Analisis kualifikasi KPMM peserta didik sebelum dan sesudah penerapan model PBL pada materi Ukuran Penyebaran Data dapat dilihat pada Tabel 8 berikut.

Tabel 8. Peningkatan pada Setiap Kualifikasi KPMM Peserta Didik

\begin{tabular}{lcc}
\hline \multirow{2}{*}{ Kualifikasi } & \multicolumn{2}{c}{ Jumlah Peserta Didik } \\
\cline { 2 - 3 } & Siklus I & Siklus II \\
\hline Sangat Baik & 18 & 27 \\
Baik & 11 & 9 \\
Cukup & 6 & 3 \\
Kurang & 4 & 0 \\
Sangat Kurang & 0 & 0 \\
\hline
\end{tabular}

Berdasarkan data pada Tabel 8, diperoleh informasi bahwa dengan penerapan PBL, KPMM pada setiap kualifikasi memperoleh peningkatan. Hal ini terlihat dari peningkatan jumlah peserta didik pada kualifikasi sangat baik, yaitu sejumlah 27 orang dan pada kualifikasi baik sejumlah 9 orang, serta kualifikasi cukup sebanyak tiga orang dan tidak ada satu pun peserta didik pada kualifikasi kurang serta sangat kurang.

Berdasarkan pelaksanaan proses pembelajaran yang telah peneliti lakukan, pembelajaran telah sesuai dengan amanat Kemendikbud yang tertuang pada Permendikbud Nomor 22 Tahun 2016, yaitu pembelajaran berlangsung secara interaktif, inspiratif, menyenangkan, menantang, efisien, memotivasi peserta didik untuk berpartisipasi aktif, serta memberikan ruang yang cukup bagi prakarsa, kreativitas, dan kemandirian sesuai dengan bakat, minat, dan perkembangan fisik serta psikologis peserta didik. Pembelajaran juga telah mengikuti prinsip-prinsip yang telah ditetapkan pada Permendikbud Nomor 22, yaitu dari peserta didik diberi tahu menuju peserta didik mencari tahu, serta dari guru sebagai satusatunya sumber belajar menjadi belajar berdasarkan aneka sumber belajar.

Berdasarkan kriteria keberhasilan tindakan dapat dikatakan bahwa tindakan yang dilakukan peneliti telah berhasil karena adanya perbaikan proses pembelajaran dengan menerapkan PBL di kelas XII MIPA 2 SMAN 12 Pekanbaru. Sejalan dengan apa yang dikatakan oleh Wina Sanjaya (2013) bahwa PTK dikatakan berhasil jika masalah yang dikaji semakin mengerucut atau melalui tindakan setiap siklus masalah semakin terpecahkan. Dilihat dari aspek hasil belajar, pencapaian peserta didik semakin tinggi, artinya hasil belajar dari siklus I ke siklus II semakin meningkat.

Terdapat beberapa kendala selama proses penelitian, hal ini tidak terlepas dari kekurangan peneliti dalam proses pembelajaran, di antaranya pada siklus pertama proses pembelajaran belum seluruhnya sesuai dengan perencanaan. Alokasi waktu yang tidak sesuai dengan perencanaan, peneliti yang tidak menyampaikan teknik penilaian, peserta didik yang cenderung bekerja secara individu, peneliti tidak memberikan tes formatif pada pertemuan pertama, kurangnya pemahaman peserta didik terhadap langkah-langkah pengerjaan LKPD serta kurangnya motivasi yang diberikan oleh peneliti. Kekurangankekurangan ini menjadi bahan perbaikan bagi peneliti untuk dilakukan pada siklus kedua. Berdasarkan KPMM peserta didik yang diperoleh dari ulangan harian I, peneliti menekankan kembali kepada peserta didik tentang pentingnya langkah-langkah pengerjaan LKPD. Proses pembelajaran pada siklus kedua mengalami perbaikan dari proses pembelajaran pada siklus pertama karena peserta didik sudah terbiasa mengikuti proses pembelajaran menggunakan PBL. Proses pembelajaran pada siklus kedua sudah sesuai dengan perencanaan.

Kesalahan yang dilakukan peserta didik berdasarkan analisis ketercapaian aspek KPMM peserta didik pada hasil ulangan harian I dan ulangan harian II adalah peserta didik tidak menyelesaikan perencanaan masalah dan peserta didik kurang teliti dalam menyelesaikan operasi hitung serta peserta didik juga tidak melaksanakan semua langkah penyelesaian dalam pemecahan masalah. Ide perbaikan kesalahan peserta didik disarankan kepada guru dalam pelaksanaan pembelajaran selanjutnya. Pembelajaran sebaiknya dilakukan dengan menambah soal latihan berbentuk pemecahan masalah dalam proses pembelajaran.

Terjadinya peningkatan kemampuan pemecahan masalah matematika disebabkan karena dalam PBL peserta didik bersama kelompok diberikan kesempatan untuk berpartisipasi aktif menemukan pengetahuannya serta menyelesaikan masalah dari materi yang dipelajari secara mandiri, sehingga pembelajaran menjadi bermakna dan pengetahuan yang diperoleh bertahan lama, 
serta peserta didik terbiasa menggunakan logika berpikir dalam pemecahan masalah. Sejalan dengan pernyataan bahwa model PBL adalah model pembelajaran dengan pendekatan pembelajaran peserta didik pada masalah autentik, sehingga peserta didik dapat menyusun pengetahuannya sendiri, menumbuh kembangkan keterampilan yang lebih tinggi dan inquiri, memandirikan peserta didik, dan meningkatkan kepercayaan diri sendiri (Arends, 2013).

PBL dalam penelitian ini meningkatkan KPMM peserta didik sebagaimana penelitian terdahulu yang telah dilakukan beberapa peneliti, di antaranya penelitian yang dilakukan Astuti, Yuanita, dan Jalinus (2015) yang menyatakan penerapan model Pembelajaran Berdasarkan Masalah meningkatkan KPMM peserta didik kelas VIII4 SMP Babussalam Pekanbaru yang diterapkan pada pembelajaran kurikulum 2013. Berdasarkan analisis aktivitas guru, aktivitas peserta didik dan analisis KPMM peserta didik dapat disimpulkan bahwa hipotesis tindakan yang diajukan dapat diterima kebenarannya.

\section{SIMPULAN}

Pada bagian ini terdapat dua hal, itu (1) Model PBL dapat memperbaiki proses pembelajaran yaitu pada siklus I terjadi ppeningkatan aktivitas peserta didik yang lebih baik; (2) Model PBL ini dapat meningkatkan kemampuan pemecahan masalah matematika peserta didik menyelesaikan masalah pada setiap indikator KPMM, dan juga dilihat dari peningkatkan prestasi peserta didik dalam kelas XII MIPA 2 SMAN 12 Pekanbaru semester ganjil tahun ajaran 2018/2019 pada materi pokok Statistika.

\section{DAFTAR PUSTAKA}

Arends, R.I. (2013). Learning to Teach 2. Jakarta: Salemba Humanika.

Arikunto, S., Suhardjono, dan Supardi. (2012). Penelitian Tindakan Kelas. Jakarta: Bumi Aksara.

Arikunto, S. (2014). Prosedur Penelitian Suatu Pendekatan Praktik. Jakarta: Rineka Cipta
Astuti, W., Yuanita, P., dan Jalinus. (2015). Penerapan Model Pembelajaran Berbasis Masalah Untuk Meningkatkan Kemampuan Pemecahan Masalah Matematis Siswa Kelas VIII4 SMP Babussalam Pekanbaru. Jurnal Online Mahasiswa (JOM) Bidang Keguruan dan Ilmu Pendidikan, 2(2), 1 - 10

Hamzah, A. (2014). Evaluasi Pembelajaran Matematika. Jakarta: Rajawali Press

Kemendikbud. (2014). Salinan Lampiran Permendikbud No. 58 Tahun 2014 Tentang Kurikulum 2013 Sekolah Menengah Pertama/Madrasah Tsanawiyah. Jakarta: Kemendikbud

Kemendikbud. (2014). Salinan Lampiran Permendikbud No. 103 Tentang Pembelajaran Pada Pendidikan Dasar dan Pendidikan Menengah. Jakarta: Kemendikbud

Kemendikbud. (2016). Salinan Lampiran Permendikbud No. 22 Tentang Standar Proses Pendidikan Dasar dan Menengah. Jakarta: Kemendikbud

Mawaddah, S., dan Anisah, H. (2015). Kemampuan Pemecahan Masalah Matematis Siswa Pada Pembelajaran Matematika Dengan Menggunakan Model Pembelajaran Genenartif (Generative Learning) di SMP. Edu-Mat, 3(2), 166 175

Muslich, M. (2010). Metode Penelitian Kualitatif. Yogyakarta: Kanisius

Sanjaya, W. (2013). Penelitian Tindakan; Jenis, Metode, dan Prosedur. Jakarta: Kencana Prenada Media Group

Sugiyono. (2012). Metode Penelitian Kuantitatif, Kualitatif, dan $R \& D$. Bandung: Alfabeta

Suryadi, D., dan Herman, T. (2008). Eksplorasi Matematika Pembelajaran Pemecahan Masalah. Bekasi: Karta Duta Wahana 